\title{
The lesson of Franklin Valley
}

SIR - I wish to dispute points raised by Professor Mulvaney (Nature 306, 636; 1983) and Dr Rhys Jones (Nature 306, 726; 1983) about my letter (Nature 305, 354; 1983) describing caves with archaeological contents outside the reservoir area for the Lower Gordon Scheme in Tasmania. It should not be forgotten that the search for these caves was an attempt to test the claims made by archeologists about the uniqueness of the Franklin Valley caves.

Archaeology was not taken lightly in the environmental studies, but in 1979 , when these studies were carried out, the archaeologists' view was that this part of Tasmania had not been occupied ${ }^{1}$. Officers of the Tasmanian Museum agree with this view, so that the curator's offer to accompany the Scientific Survey was not accepted. Two requests for archaeological assistance during this search were, however, unsuccessful because of the ban imposed by archaeologists on the recovery of relics.

From May 1979 until the dam was approved by parliament in June 1982, the commission was subject to a "moratorium" on further investigation (including archaeological research) imposed by the government. This ban did not apply to the Wilderness Society, the National Parks and Wildlife Service or to Dr Jones and it was during this period that they conducted selective studies within the reservoir area and the discovery of Kutikina Cave was announced.

Dr Jones' letter says that he and his colleagues have carried out systematic searches of several areas in Northern Tasmania, but he fails to mention that Southwest Tasmania has not been searched. This is a dense rainforest area that has deterred explorers, bushwalkers and archaeologists, who have deliberately refrained from investigating the Gordon Limestone in the area. Preliminary exploration was considered necessary ${ }^{2}$ and carried out by methods developed by the commission for hydro-power investigation and involving the use of helicopters. Our field geologists could readily recognize karst limestone from the air and cost was negligible compared with the loss of the power scheme. Now it is up to archaeologists to follow up these discoveries, not forgetting the 300 unexplored caves in the Florentine Valley.

The main point of difference between us is that of the need to preserve the contents of the Franklin Caves in place rather than by undisturbed recovery. The Franklin Caves contain the discards of huntergatherers and have not been shown to contain priceless works of palaeolithic art. As they are only a few of a number of caves occupied by early man in Southwest Tasmania, the call for preservation in place is unreasonable. The commission was proposing a properly engineered undisturbed recovery for which the construction schedule allowed a recovery period of 8 years. It would have been a fruitful period for co-operation between geomechanics scientists and archaeologists with the opportunity to develop new techniques.

I think the lesson of the whole controversy is that multidisciplinary scientific co-operation is much more fruitful than narrow confrontation.

\section{Chief Geologist}

\section{Hydro-Electric Commission,}

Box 355D, GPO,

\section{Hobart, Tasmania 7001, Australia}

1. Jones, R. Appendix: Tasmanian Tribes in Aboriginal Tribes of Australia (ed. Tindall, N.B.) (A.N.U. Press, 1974)

2. Jones, R. Senate Select Commitee on South West Tasmania Official Hansard Report, Commonwealth of Australia, Canberra, 1982).

\section{Indian symposium}

SiR - We have read the news item in Nature (1 March p.6) regarding the inability of Israeli scientists to attend the VIIth International Biotechnology Symposium. To put the record straight, the organizers did everything possible to help the scientists from Israel to attend the symposium. In fact, it can be categorically stated that Indian colleagues greatly looked forward to having them at the symposium. The files of the organizing committee are open to inspection by IUPAC, the sponsor of the symposium, to confirm the large and expensive efforts put in to facilitate participation of everyone who desired and its communication with the delegates and the government to expedite the issue of entry permits/visas.

This should answer the point of your correspondent, which appears to allege that there was a deliberate attempt to exclude the Israeli scientists from the symposium. This is far from true. In fact, the Indian biotechnology community has great admiration for Israeli scientific efforts and contributions to biotechnology. We were therefore happy to see Professor Gutnick from the University of Tel-Aviv at the symposium. Normal methods of obtaining visas were available to Israeli scientists at the nearest Indian mission and our records show all missions were duly advised by the Indian authorities to issue visas to registered delegates largely as a result of the organizing committee's efforts.

Furthermore, Alitalia, the Italian airline, could have arranged for tourist visas to enable them to visit India in accordance with your correspondent's letter from Rehovot. To say as Dr Gressel has done that "the Indian Embassies concerned usually claimed to have no record of their request" to Dr Chand is clearly uncalled for.

In fairness to all, the confusion probably arose because this was the first international conference held in India after the change in the rules (withdrawal of landing permit facility) where a large number of Israeli delegates were registered. In a democracy delay sometimes occurs and it is unfair and counter-productive to suggest that this is intentional. In fact a significant number of Israeli scientists attended meetings held before November 1982 when the practice of providing landing permits was in vogue.

T.K. GHOSE

\section{National Coordination Committee,}

VIIth International Biotechnology

Symposium,

Indian Institute of Technology, New Delhi-110016, India

SIR - In Nature of 2 February $(307,408$; 1984) you printed a letter from Dr J. Stefan Roken calling on scientists to boycott the International Biotechnology Symposium held in New Delhi in February, and calling for protests against the Indian Government for not permitting scientists from all countries to participate at the symposium.

The Department of Science and Technology, Government of India, has confirmed that permission was indeed given to Israeli scientists to participate in this symposium and that this fact had been communicated to Indian missions abroad. Israeli scientists did in fact participate, although not in the numbers originally expected.

P.L. SINA!

Embassy of India,

Washington, DC 20008, USA

\section{"Wine-dark sea"}

SIR - I refer to Nature of 12 April, p.580. Seldom can a problem - the nature of Homer's "wine-dark" sea - have resulted so rapidly in just the right research proposal to solve it. On page 12 of classified advertising, the University College of North Wales, Bangor, is seeking a Research Officer to investigate "ocean colour".

\section{Y.M. CHAMBERLAIN}

4 Shelley Close,

Itchen Abbas,

\section{Winchester SO21 1AU, UK}

SIR - I think Jonathan Treitel (Nature 12 April, p.580) is correct in ascribing this strange description to a lack of colour sense on the part of the Greeks. When I taught chemistry in Nigeria a fairly major problem was that many students never knew when indicators had changed colour; one had to hang a colour chart on the wall for comparison. This had nothing to do with eyesight, for the students in question learnt eventually, it was simply a matter of lack of practice in colour recognition. It was a little unnerving to be asked by a student clutching a piece of litmus paper "please sir, has this changed colour?". Those trained from infancy in colour recognition find it hard to believe it, but experience shows that it can be a problem.

University of Natal,

King George V Avenue, Durban 4001, Republic of South Africa 